International Journal of

Supply Chain and Logistics

(IJSCL)

STAKEHOLDER INVOLVEMENT AND NATURE OF PROCUREMENT PROCESS IN THE UNITED NATIONS ORGANIZATION STABILIZATION MISSION IN THE DEMOCRATIC REPUBLIC OF CONGO (MONUSCO) ENTEBBE SUPPORT BASE

Gatta Ouyabaka Marius

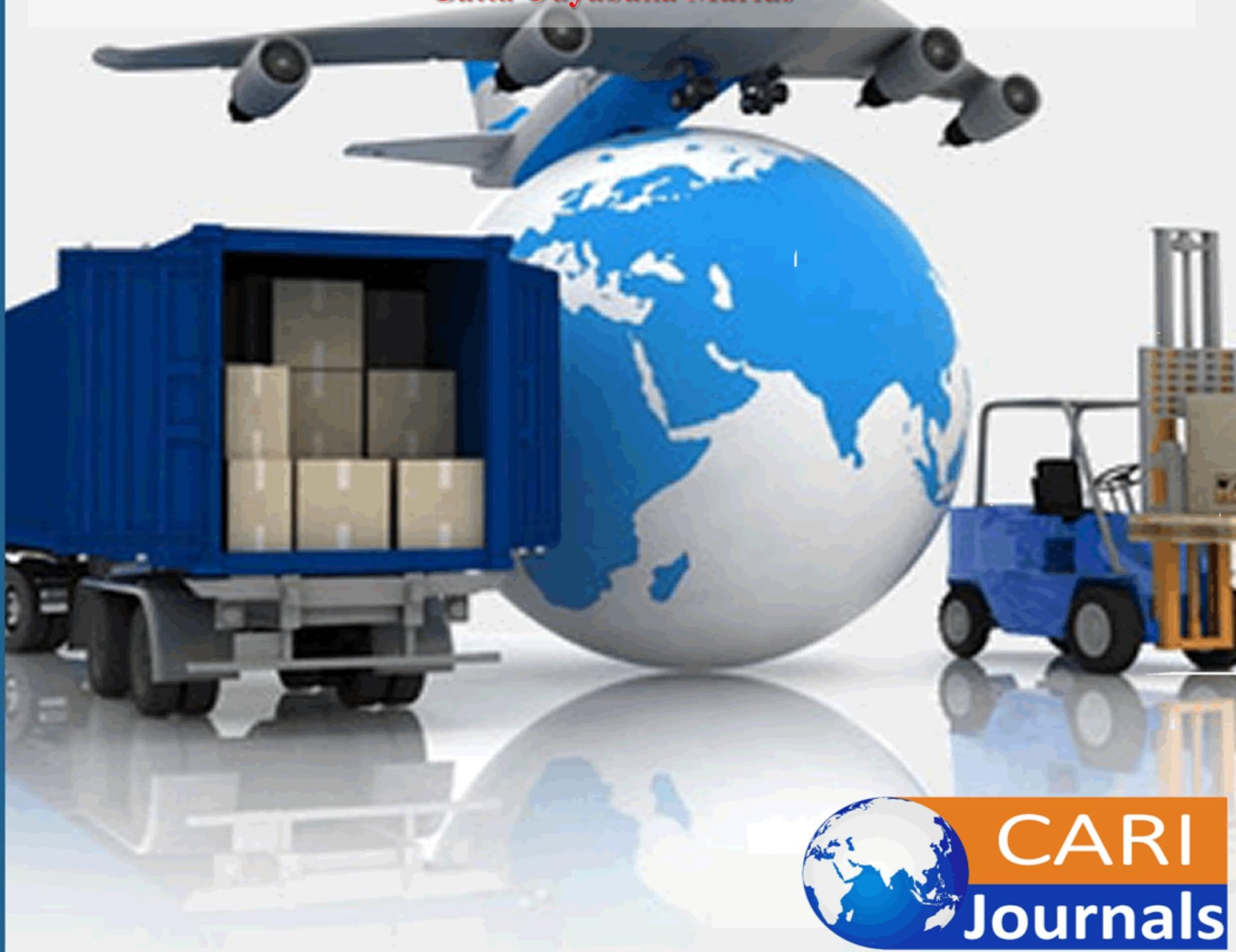




\title{
STAKEHOLDER INVOLVEMENT AND NATURE OF PROCUREMENT PROCESS IN THE UNITED NATIONS ORGANIZATION STABILIZATION MISSION IN THE DEMOCRATIC REPUBLIC OF CONGO (MONUSCO) ENTEBBE SUPPORT BASE
}

\author{
1* Gatta Ouyabaka Marius \\ ${ }^{1}$ Post Graduate Student: Nkumba University \\ *Corresponding Author’s E-mail: marius.gatta@gmail.com
}

\begin{abstract}
Purpose: The purpose of this study was to examine the nature of procurement process followed by MONUSCO and the involvement of stakeholders in this process.

Methodology: The study employed a descriptive case study design. The target population comprised of 261 employees of MONUSCO Entebbe Support Base holding international, United Nations Volunteers (UNV) and National contracts. Random and purposive sampling techniques were specifically used to select samples for this study. Data was collected using questionnaires and interview guides. The quantitative data collected was further analysed using SPSS for descriptive and inferential statistics while the qualitative data was analysed using content analysis.

Findings: The study findings showed that there is procurement planning in most MONUSCO sections; that funds are available before planning; that staff are involved in procurement planning in their respective sections; and that procurement planning contributes to achieve the maximum value for expenditures on goods/services and works to be delivered at MONUSCO sections. The study found that procurement planning had led to improved levels of MONUSCO operations in the areas of humanitarian relief, peacekeeping, development assistance to affected communities. The study further found that staff are involved in the identification and definition of the needs of user sections and that the Statement of Requirements (SOR)/or Scope of Work (SOW) was important in their respective sections. These had aided in full scale involvement of relevant stakeholders in the procurement planning activities of MONUSCO ESB.
\end{abstract}

Unique contribution to theory, practice and policy: The study recommends a clear determination of specifications in terms of required quality and quantities by the end-user departments in MONUSCO ESB. Planning and determination of needs should be done early to allow enough time to initiate the procurement process. The study further recommends that the procurement department should always engage all concerned stakeholders in determining the materials and service specification for quality assurance during service delivery. This will enable the sections to always get the quantity of items as requested by end-users, in their right quantity, right quality and at the right time.

Keywords: stakeholder involvement, procurement process, procurement planning, MONUSCO 


\subsection{INTRODUCTION}

Procurement is an internationally recognized profession. Organisations aim at getting the best value product or service by encouraging openness, developing the relationships with potential suppliers, engaging with service users and marketing opportunities widely. The purchasing profession has been gaining recognition in developed countries faster than in the developing countries (Matechak, 2009). Worldwide, public procurement has become an issue of public attention and debate, and has been subjected to reforms, restructuring, rules and regulations. Public procurement refers to the acquisition of goods, services and works by a procuring entity using public funds (World Bank, 1995a). Procurement process starts when an entity has identified a need and decided on its procurement requirement. Procurement goes through the process of risk assessment, seeking and evaluating alternative solutions, contract award, delivery of, and payment for the property and/or services and, where relevant, the ongoing management of a contract and consideration of options related to the contract. Procurement also extends to the ultimate disposal of property at the end of its useful life (Mugerwa, 2010).

Furthermore, the procurement function is responsible on one hand for the identification of the end-user's needs and, by utilizing suppliers, meeting them. Therefore, by its very nature, procurement is a "service" function (Ishola, 2010). In this study, procurement is defined as service functions provided by a dedicated team of professionals operating at the interface between the organizations' suppliers and the end-user department (s) in order to effectively and efficiently meet the supplies needs of the organization. According to Ellaram et al. (1989), in procurement, customer service outcome exists in two domains; the supplier activity domain and the end-user response domain. Thus, the study identifies two customers to the procurement function: internal and external i.e. the end users and the suppliers respectively. In a procurement process therefore, efforts must be dedicated to ensuring the complete satisfaction of not only the end-user or customer of a product and/or service, but, also the satisfaction of the suppliers whose products or service are incorporated into the end- user /customer order and whose performance impacts the end user satisfaction (Gordon, 2009).

Procurement process is a key function which impacts can be effective or 'ineffective' on service delivery. There is no part of local government service delivery that does not depend on procurement of goods, services and works; and yet the area remains a neglected field of research (Oboth, 2001). According to Helmsing (1995), the importance of procurement reform in almost all country's settings can be demonstrated based on its scale and role in terms of service delivery, the amount stated wasted by existing practices, reduced competition, higher prices due to market perceptions of risks, as well as the demonstrated ability of countries to capture enormous savings through concerted efforts to strengthen their procurement function (Agaba \& Shipman, 2007).

Procurement in the United Nations (UN) has also undergone significant transformation since reforms were initiated in 1999. The main issues taken into consideration as part of the UN procurement reform can be found in several UN official documents, particularly Resolution A/RES/54/14 of November 1999. The Resolution specifies the direction that procurement reform initiatives need to follow in order to strengthen the principles of transparency, effectiveness and efficiency while also fully reflecting the international character of the United Nations. Procurement has evolved from a simple buying function to become recognized as a professional role within the UN as well. Procurement officers and those acting in, or supporting that function, are in a special position of trust and are held to high standards of professionalism. Development 
of professional and ethical competencies of UN procurement officers is recognized as an important component of the UN procurement reform process.

Procurement officers operate within a complex environment. They are subject to pressure from end-users seeking rapid response or a specific technical solution, from suppliers seeking invitations or contracts, from donor representatives or the public seeking explanation for the use of the funds, and by anyone who thinks they detect a lack of transparency or other weakness in the process. In all UN organisations, procurement has an impact on the overall organisational outcomes and results. It is therefore good practice to undertake strategic planning of procurement at the organisational level in order to link procurement activities and priorities to the overall priorities of the organisation. Strategic planning is also important in order to manage the risks and the total costs involved in procurement, including use of resources.

Poor service delivery can be justified by ineffective procurement systems within an organization. Procurement planning for instance is a factor influencing service delivery. Mullins (2003) asserts that the contribution of procurement planning in facilitating an efficient and effective service delivery in public sector organizations is generally undisputed in both developed and developing countries. A sound procurement system has to have a competent professional workforce equipped with defined skills and knowledge for specified procurement jobs (OECD-DAC, 2006).Creating a procurement workforce with the right skills and capabilities can be a challenge, given changes to procurement processes, the introduction or expansion of alternative contracting approaches, and increased reliance on services provided by the private sector (Government Accountability Office, 2005).

Expectations for effective service delivery in peacekeeping missions keep increasing in most of the affected countries where UN Missions (currently there are 16 UN peacekeeping missions in the world) operate. The largest UN peacekeeping mission is MONUSCO. The Security Council established the United Nations Organization Mission in the Democratic Republic of the Congo (MONUC) by its Resolution 1279 of 30 November 1999 (S/RES/1279; 30 November 1999). In MONUSCO as well as in all UN agencies, procurement is a function through which the organisation meets its goals and objectives by exploiting the available resource in efficient and effective way.

The MONUSCO Entebbe Support Base is the main logistic hub where $80 \%$ of the purchased commodities to support MONUSCO operations are received and thereafter dispatched all over the mission area in the Democratic Republic of Congo (DRC). In his report dated February 2016 to the Fifth Committee (the 5th Committee of the General Assembly with responsibilities for administration and budgetary matters. Based on the reports of the Fifth Committee, the General Assembly considers and approves the budget of the Organization in accordance with Chapter IV, Article 17 of the Charter of the United Nations. This function was reaffirmed by the General Assembly in its resolution 45/248 B, Sect. VI), the Chief of Entebbe Support Base has emphasized on the strategic logistic role of the ESB.

The MONUSCO Entebbe Support Base was established by MONUSCO (formerly MONUC) in 2006 near the Entebbe International Airport to provide logistics and operational support to Eastern Democratic Republic of Congo. Since its establishment, the proven operational capabilities of this facility coupled with the strategic location to neighboring missions, the reliable logistic infrastructure and the political stability of Uganda were all valuable 
considerations which prompted the expansion of ESB to its current capacity 9152,000 square meters). MONUSCO ESB staff in 2015 is 810, comprising of International Staff, United Nations Volunteers, Nationally recruited staff, as well as contractors and uniformed personnel (military and United Nations police).

Besides it primarily role of supporting the logistic operations in DRC, MONUSCO ESB is currently serving eleven different UN entities located in its premises. The support provided continues to expand with a call for quality services through a coordinated delivery system. Consequently, this study had identified limited gap in existing empirical literature as it relates to service delivery addressing procurement related issues in the logistic support provided to MONUSCO. It is against this background that the study sought to fill the gap by evaluating the nature of procurement process followed by MONUSCO and the involvement of stakeholders in this process.

\subsection{Statement of the problem}

Although UN has sound procurement rules, policies, guidelines and regulations to ensure best value for money and to effectively and efficiently support its operations, several reports and complaints indicated that services are not delivered to the full expectations of end-users. Within MONUSCO ESB, physical interactions with end-users and various stakeholders, reports and emails have highlighted the quality of services and/or commodities and shown growing dissatisfaction and queries towards procurement practices in MONUSCO.

In fact, several complaints pointed out the level of dissatisfaction among various stakeholders and end-users. The Regional Training Centre and Conference (RTCC) issued an Interoffice Memorandum dated 23 November 2011 (Ref. RSC/RTCC/2011/237) following several complaints from training participants about the quality of pens. Consequently, 114,621.00 pens valuing USD \$98756.31 were returned to stock and thereafter written - off. In May 2014, following the expansion of the Regional Service Centre Entebbe (RSCE), Supply section was urgently requested to locally acquire office furniture to support the relocation of 200 staff to ESB. Due to the urgency of the move, office furniture which was locally purchased was found to be of poor quality, resulting in raising complaints from end-users.

Following a delay in procurement planning in 2014, MONUSCO faced a shortage of office supplies, which had led for an emergency purchase of USD 150,000.00 (Ref. Fund Commitment\# 3000003042). On 23 January 2015, a vendor who had been issued a contract to supply office stationeries and supplies, failed to timely deliver the order, thus leading the Mission to urgently look for another supplier to cater for its urgent logistic requirements. Besides, the partially delivered goods were of poor quality resulting in increasing the dissatisfaction of end-users and queries about the vendor's evaluation and capacity to meet its contractual obligations. A Vendor Performance Report dated 16 June 2015 was raised and sent to Procurement for appropriate action against the vendor without any success.

It is based on such evidence that the study is carried out to investigate the role of procurement process in ensuring effective service delivery in United Nations Entebbe Support Base. Therefore, this study sought to examine the nature of procurement process followed by MONUSCO and the involvement of stakeholders in this process. 


\subsection{Research Objective}

To examine the nature of procurement process followed by MONUSCO and the involvement of stakeholders in this process

\subsection{LITERATURE REVIEW}

\subsection{Theoretical Review}

\subsubsection{Institutional Theory}

According to Scott (2004), institutions are composed of cultural-cognitive and regulative elements that, together with associated activities and resources give meaning to life. He further explains the three pillars of institutions as regulatory, normative and cultural cognitive. The regulatory pillar emphasizes the use of rules, laws and sanctions as enforcement mechanism, with expedience as basis for compliance. The normative pillar refers to norms (how things should be done) and values (preferred or desirable), social obligation being the basis of compliance. The cultural-cognitive pillar rests on shared understanding (common beliefs, symbols, shared understanding). This theory is very important when it comes to the implementation of sustainable procurement policy and practice in organizations that serve the public. This is a matter of organizational culture and the degree to which the prevailing climate in an organization is supportive of sustainability and/or of change in general. In other respects, this dimension includes the extent to which there is support for SP at senior levels in an organization and the degree to which organizational processes and structures support, or retard, the development of SP (Brammer \& Walker, 2007).

\subsubsection{Socio-economic Theory}

Sutinen and Kuperan (1999) propounded the socio-economic theory of compliance by integrating economic theory with theories from psychology and sociology to account for moral obligation and social influence as determinants of individuals' decisions on compliance. According to Lisa (2010) psychological perspectives provide a basis for the success or failure of organizational compliance. Wilmshurst and Frost (2000) also add that the legitimacy theory postulates that the organization is responsible to disclose its practices to the stakeholders, especially to the public and justify its existence within the boundaries of society. This theory, which focuses on the relationship and interaction between an organization and the society, provides a sufficient and superior lens for understanding government procurement system (Hui et al., 2011). From this theory, one can understand the policy, planning and sustainable procurement practices in public institutions and their influence on service delivery to the society.

\subsection{Procurement Process}

According to Simchi-Levi, Simchi-Levi, and Kaminsky (2009), the procurement function is responsible on one hand for the identification of the end-user's needs and, by utilizing suppliers, meeting them. By its very nature therefore, procurement is a "service" function (Ishola, 2010). Hence, in this paper we define procurement as a service function provided by a dedicated team of professionals operating at the interface between the organisation's suppliers and the end-user department (s) in order to effectively and efficiently meet the supplies needs of the organisation. According to Ellaram et al. (1989) in procurement customer service outcome exists in two domains; the supplier activity domain and the end-user response domain. 
We, thus, identify two customers to the procurement function: internal and external i.e. the end users and the suppliers respectively. In a procurement process therefore, efforts must be dedicated to ensuring the complete satisfaction of not only the end-user or customer of a product and/or service, but, also the satisfaction of the suppliers whose products or service are incorporated into the end- user /customer order and whose performance impacts the end user satisfaction (Gordon, 2009).

In the United Nations Procurement Manual, Revision 7 (2013) the purchasing process for companies breaks down into eight clear steps. In the first step the company identifies a need, for which the answer is the purchase of a product. The final step is the execution of a purchase contract. The steps in between build an organized, informed process that results in the company purchasing the right product for the need from a qualified supplier whose product is the most durable for the price.

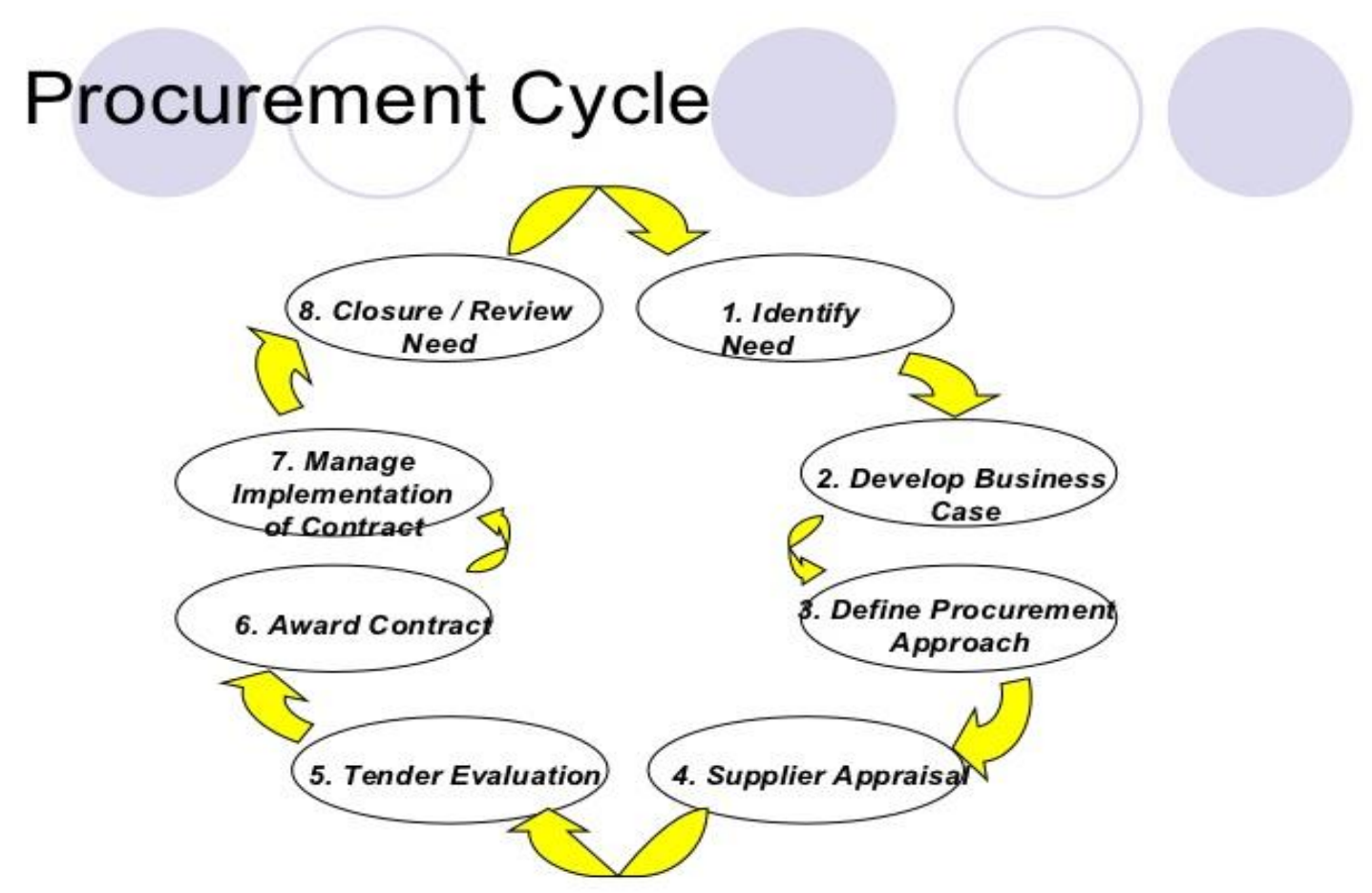

\section{Figure 1: Procurement Cycle flow chart according to the UN Procurement Manual}

According the United Nations Procurement Manual, Revision 7 (2013) The UN procurement process involves a wide-range of activities including: acquisition planning; drafting; reviewing or approving Specifications, SOWs and TORs; identifying, registering and evaluating Vendors; preparing and developing Solicitations; evaluating Bids or Proposals; Source Selection; negotiating price or terms and conditions of Contracts; reviewing and approving awards of Contracts; providing legal services including drafting Contracts; signing Contracts and Purchase Orders; receiving and inspecting goods or services; performing oversight services; managing Contracts; reviewing Vendor Performance; certifying, approving and making payments pursuant 
to large and complex Contracts; and handling Vendor protests or disputes regarding the procurement process.

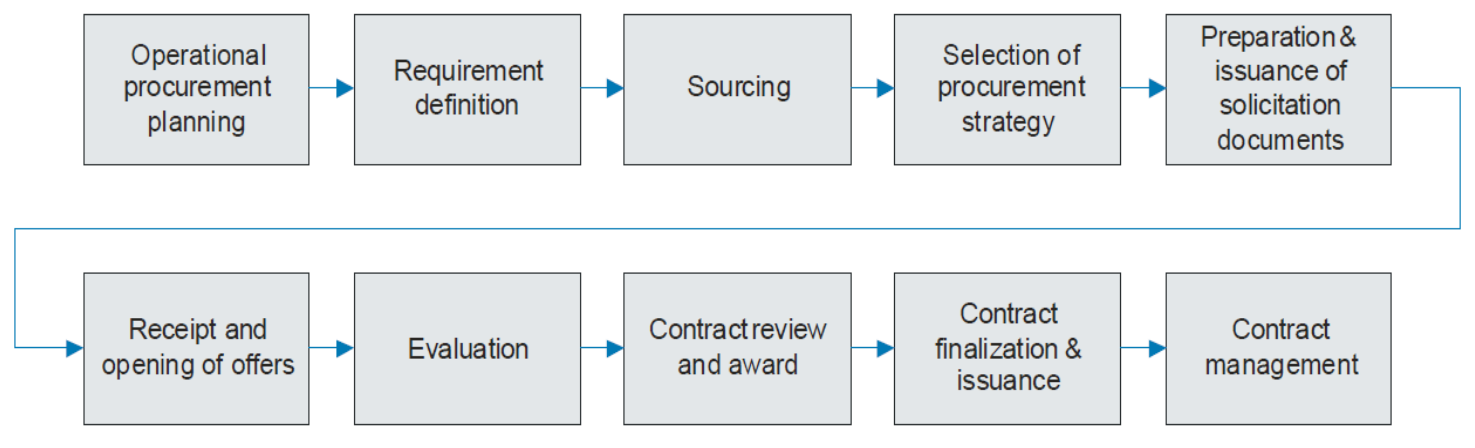

\section{Figure 2: Procurement Process Flow Chart of the United Nations}

A key aspect of the procurement process outlined in UN Procurement Practitioner's Handbook (2006) Manual begins with the registration of potential recipients of UN Solicitation Documents. It is the procurement staff responsibility to further develop the sourcing by identifying vendors that will meet the Requisitioner's requirements. The UN in its sole discretion determines whether a Vendor is eligible for registration, and continues to remain eligible, for the purpose of establishing a pool of prospective UN Vendors. Such Vendors may be invited to participate in a particular Solicitation. Determination of eligibility for registration is a UN prerogative. Thereafter, the UN receives and evaluates responses to Solicitations, determining whether the Vendor is both qualified and meets the requirements of Financial Rule 105.15(a) for Bids or (b) for Proposals. The UN decides which Vendor to select and notifies it of its intention to award a Contract. The successful Bidder, following Contract negotiations (if any) and the signature of a Contract, would then become a UN contract or whose relationship vis-à-vis the UN is governed by the contract formation processes outlined in this Procurement Manual. Unsuccessful Bidders will be notified accordingly and may be granted a debriefing.

This study did not intend to evaluate the entire procurement process stages but to focus on the following: operational procurement planning and need identification and requirement definition.

\subsubsection{Procurement Requirements Definition}

It is the role of each entity in the local government to define its procurement requirements, identify all of the items they need to procure (Agaba \& Shipman, 2007). Creating a sound financial justification for procuring them, listing all the tasks involved in procuring their services, scheduling those tasks by allocating timeframes and resources. Through a Procurement Plan template, the procuring entity can quickly and easily define its procurement requirements, the method of procurement and the timeframes for delivery (Basheka, 2008).

\subsubsection{Identification of Desired Procurement Outcomes and Objectives}

The first step in the planning process is to identify the desired outcomes and objectives of the procurement. However the process is not necessarily linear. In some cases information obtained 
in the informational gathering stage will also have an impact on the identification of objectives. For example, an analysis of the supply market shows that there are limited sources of supply which means that a key objective is to identify suppliers who can develop alternative products. This, in turn, will have an impact on the requirement definition stage of the process.

The complexity of this process will vary from case to case. In some instances, for example where the requirement is for a commodity used across the organization with high volume, e.g. vehicles, the objectives and the desired outcomes of the procurement action may already be clearly defined in the organization's procurement strategy. In other instances, such as the procurement of a complex and high value solution that is critical to the organization or the client, then there may be a complex network of stakeholders each with their own ideas of objectives and desired outcomes.

\section{- Stakeholders}

Where the situation is complex it can be a good idea to systematically analyse the stakeholders involved. Stakeholders are anyone who has an interest in procurement activities delivering actual or perceived objectives. They can include development partners, clients, end-users, civil society, senior management, finance, technical experts, etc. It is important to identify the interests and relative importance of each stakeholder. Sometimes the interests of various stakeholders can be in conflict or competition with each other. In practice the procurement officer usually needs to develop a collaborative, but focused relationship with key stakeholders.

This includes listening to their concerns and ideas, seeking their agreement where necessary, keeping them informed, challenging their needs and wants, and adapting to their needs where necessary. Nevertheless, in this process, the procurement officer at the same time needs to represent and defend the interest of the UN organization within its regulative and procedural framework. Specific objectives of key stakeholders may relate to: delivery times, adherence to specific regulatory frameworks, sourcing from specific groups of suppliers and use of specific brands, if justified.

These stakeholder objectives need to be combined with the information gathered during the requirement specification and supply market analysis and the organization's overall procurement strategy. Then, if necessary through a collaborative process, the objectives and outcomes for the procurement should be agreed. At this time performance measures and indicators should also be agreed which will enable the procurement officer to determine whether the agreed procurement objectives have been met.

\subsubsection{Procurement Planning}

There is very limited doubt among policy makers, managers, professionals and academicians about the role of public procurement planning in facilitating government operations in both developed and developing countries (Goh, Lau, \& Neo, 1999). Public procurement is increasingly recognized as a profession that plays a significant role in the successful management of public resources. According to Agaba and Shipman, (2007), procurement planning is the process used by companies or public institutions to plan purchasing activity for a specific period of time. This is commonly completed during the budgeting process. Each year, departments are required to budget for staff, expenses, and purchases. This is the first step in the procurement planning process. Economic commission of Africa (2003) defines procurement planning as the purchasing function through which organization obtains products and services 
from external suppliers. A good procurement plan will go one step further by describing the process to go through to appoint those suppliers contractually. Whether you are embarking on a project procurement or organizational procurement planning exercise, the steps will be the same. First, define the items you need to procure. Then, define the process for acquiring those items. And finally, schedule the timeframes for delivery.

Mawhood (1983) noted that the ultimate goal of procurement planning is coordinated and integrated action to fulfil a need for goods, services or works in a timely manner and at a reasonable cost. Early and accurate planning is essential to avoid last minute, emergency or illplanned procurement, which is contrary to open, efficient and effective and consequently transparent procurement. In addition, most potential savings in the procurement process are achieved by improvements in the planning stages. Procurement planning is a factor influencing service delivery. Johan, (2006) came up with some important service delivery improvement slogans. He said he who fails to plan for service delivery, plans to fail delivering services to the public. Basheka (2004) argues that procurement planning is one of the primary functions of procurement with a potential to contribute to the success of government operations and improved service delivery. It is a function that sets in motion the entire acquisition/procurement process of acquiring services in local governments.

Mullins (2003) asserts that the contribution of procurement planning in facilitating an efficient and effective service delivery in public sector organizations is generally undisputed in both developed and developing countries. Mawhood (1983) further adds that effective procurement planning is an important route towards securing the right service to be delivered to the public, and also maximizing the level of service provision which can be achieved within the local Supporting People. A procurement plan helps Procuring Entities to achieve maximum value for expenditures on services to be delivered and enables the entities to identify and address all relevant issues pertaining to a particular procurement before they publicize their procurement notices to potential suppliers of goods, works and services.

Procurement planning clarifies what is needed and when it is needed to both user and buyer. The United Nations Procurement Manual, Revision 7 (2013) observed that effective procurement planning enables the UN organization and its staff to work smoothly to achieve the organization's goals with the right quality and quantity of inputs in place; ineffective procurement planning may result in failure to achieve those goals, putting in jeopardy the FRR and procurement principles and causing damage to the credibility of the organization.

Ishola (2010) noted that even in situations where planning is difficult such as emergencies, proactive measures can be taken to ensure contingency planning to be better prepared to address upcoming procurement requests. For example: advance identification of suitable suppliers of potential products frequently requested in emergency operations, including confirmation by suppliers on willingness to respond on short notice; and Development of standard specifications/Terms Of Reference (TOR)/Scope Of Work (SOW) for products/services/works requested in emergency operations.

Good procurement planning is essential to optimize the contribution of the procurement function towards achieving the overall goals of the organization (Gonzalez-Benito: 2007). It supports:

- Transparency. 
- Development of Key Performance Indicators (KPIs) according to milestones and accountabilities set in the procurement plan and use of the same to monitor performance.

- Effective and timely solicitation of offers, award of contracts and delivery of the goods, services and works required.

- Early requisition to reduce any delays in procurement and timely delivery to project sites.

- Early identification of right commodities and quantities to meet programme needs.

- Sourcing the right suppliers on time to avoid cutting corners under rush procurement to meet deadlines or budget expenditure.

- Effective supply strategy and timely programme and project implementation.

- Avoidance of unnecessary exigencies and urgencies, enabling full competition and full compliance with standard rules and procedures.

- Sufficient time to fully explore alternative procurement approaches, such as joint bidding with other organizations and use of Long Term Agreements (LTAs) of others.

- Strengthened procurement power vis-à-vis suppliers.

- Obtaining best prices for aggregate requirements.

- Establishment of criteria to measure effectiveness of the procurement function.

- Systematic and procedurally correct procurements as well as development of long term agreements.

- Procurement planning clarifies what is needed and when it is needed to both user and buyer.

- Effective procurement planning enables the UN organization and its staff to work smoothly to achieve the organization's goals with the right quality and quantity of inputs in place; ineffective procurement planning may result in failure to achieve those goals.

\subsubsection{Procurement Planning and Service Delivery}

Defining and planning requirements in procurement is a factor which influence service delivery. Each user department should prepare a multi-annual rolling work plan for procurement based on the approved budget, which is submitted to the procurement and disposal unit to facilitate orderly execution of annual procurement activities. A procurement plan is integrated into the annual and multi-annual sector expenditure programme to enhance financial predictability, accounting and control over procurement budgets. A procurement and disposal unit uses the combined work plan to plan, organize, forecast and schedule the procuring and disposing entity's procurement activities for the financial year, section 96 of the PPDA regulations (2006).

Johan, (2006) came up with some important service delivery improvement slogans. He said he who fails to plan for service delivery, plans to fail delivering services to the public. Basheka (2004) argues that procurement planning is one of the primary functions of procurement with a potential to contribute to the success of government operations and improved service delivery. It is a function that sets in motion the entire acquisition/procurement process of acquiring services in local governments. Mullins (2003) asserts that the contribution of procurement planning in facilitating an efficient and effective service delivery in public sector organizations is generally undisputed in both developed and developing countries. Mawhood (1983) further adds that effective procurement planning is an important route towards securing the right service to be delivered to the public, and also maximizing the level of service provision which can be achieved within the local Supporting People. A procurement plan helps Procuring Entities to achieve 
maximum value for expenditures on services to be delivered and enables the entities to identify and address all relevant issues pertaining to a particular procurement before they publicize their procurement notices to potential suppliers of goods, works and services.

A sound procurement system has to have a competent professional workforce equipped with defined skills and knowledge for specified procurement jobs (OECD-DAC, 2006). Creating a procurement workforce with the right skills and capabilities can be a challenge, given changes to procurement processes, the introduction or expansion of alternative contracting approaches, and increased reliance on services provided by the private sector (Government Accountability Office, 2005). The procurement workforce "permeates virtually every effort within an agency, including successfully acquiring goods and services and executing and monitoring contracts" (Government Accountability Office, 2005). Procurement must take a thoroughly professional view of its role in business as a whole and that must include planning (Bailey et al., 1998). One should also note that financial management, in service organizations has been a constraint and an obstacle to other functions that contribute to service delivery (Adams \& Colebourne, 1999).

\subsection{RESEARCH METHODLOGY}

The study employed a descriptive case study design. The study population comprised of 261 staff members holding international, United Nations Volunteers (UNV) and National contracts. Both probability and non-probability sampling methods were used to select the respondents. Random and purposive sampling techniques were used to select samples for this study. Two research instruments namely self-administered questionnaires and interview guides were used for data collection. The quantitative data collected was further analysed using SPSS where descriptive and inferential statistics were generated while the qualitative data was analysed using content analysis.

\subsection{RESULTS AND FINDINGS}

\subsection{Response Rate}

A total of 158 questionnaires administered to the selected respondent where a total of 133 questionnaires were properly filled and returned. This represented an overall successful response rate of $84.18 \%$ which was very adequate for this study.

\subsection{The Nature of Procurement Process Followed By MONUSCO and the Involvement of Stakeholders in this Process}

The objective of this study was to examine the nature of procurement process followed by MONUSCO and the involvement of stakeholders in this process. The respondents were asked to respond to various statements on a given scale. The findings are as in the following sub sections

\subsubsection{Existence of Procurement Planning in MONUSCO Sections}

Procurement, according to Mangan et al. (2008) is a process of identifying and obtaining goods and services. It includes sourcing purchasing and covers all activities from identifying potential suppliers through to the delivery from suppliers to the users or beneficiary. Hence, the respondents were asked whether there was procurement planning in MONUSCO sections and responses obtained are shown in the Table 1. The results show that, 4 (3.0\%) of the respondents strongly disagreed, $10(7.5 \%)$ disagreed, $9(6.8 \%)$ were neutral, $64(48.1 \%)$ agreed and 46 
(34.6\%) of them strongly agreed. Results obtained indicate that $110(82.7 \%)$ of the respondents generally agreed that indeed there is procurement planning in most MONUSCO sections at the UN Base Entebbe. During the interviews respondents revealed that "section heads are mandated to conduct thorough planning of the procurement activities and requirements for smooth service delivery" of the MONUSCO Entebbe Support Base (ESB). This has improved on the levels of MONUSCO operations in the areas of operation.

Table 1: Existence of Procurement Planning in MONUSCO Sections

\begin{tabular}{lccc}
\hline Statement & Response & Frequency & Percent \\
\hline & Strongly Disagree & 4 & 3.0 \\
& Disagree & 10 & 7.5 \\
& Neutral & 9 & 6.8 \\
& Agree & 64 & 48.1 \\
There is procurement planning in my section & Strongly Agree & 46 & 34.6 \\
& Total & 133 & 100 \\
\hline
\end{tabular}

Source: Primary data

\subsubsection{Availability of Funds before Procurement Planning}

UN organizations are the stewards of all public funds which have been provided in trust by peoples and their governments to fulfil the mandates the UN. A significant proportion of these funds are used through formal procurement processes, for which there are many stakeholders. The respondents were therefore asked whether funds were made available before planning was done in MONUSCO sections and responses obtained are shown in the Table 2.

Table 2: Availability of Funds before Procurement Planning

\begin{tabular}{lccc}
\hline Statement & Response & Frequency & Percent \\
\hline & Strongly Disagree & 6 & 4.5 \\
& Disagree & 9 & 6.8 \\
& Neutral & 21 & 15.8 \\
& Agree & 51 & 38.3 \\
Funds are available before planning is done & Strongly Agree & 46 & 34.6 \\
& Total & $\mathbf{1 3 3}$ & $\mathbf{1 0 0 . 0}$ \\
\hline
\end{tabular}

Source: Primary data

Results in the table above show that, $6(4.5 \%)$ of the respondents strongly disagreed, $9(6.8 \%)$ disagreed, $21(15.8 \%)$ were neutral, $51(38.3 \%)$ agreed and 46 (34.6\%) of them strongly agreed. Results obtained indicate that 97 (72.9\%) of the respondents generally agreed that indeed Funds are available before planning is done in MONUSCO sections at the UN Base Entebbe. During the interviews respondents revealed that "section heads are still required and mandated to draw section budgets related to procurement activities so as to have them included in the annual organizations budgets "for availability of funds needed for smooth service delivery" of the MONUSCO Entebbe Support Base (ESB). This has improved on the levels of MONUSCO 
operations in the areas of humanitarian relief, peacekeeping, development assistance to affected communities.

\subsubsection{Staff Involvement in Procurement Planning in their respective Sections}

According the United Nations Procurement Manual (2008), The UN procurement process involves a wide-range of activities including: acquisition planning; drafting; reviewing or approving Specifications. So the respondents were asked whether they are involved in procurement planning in their respective sections in MONUSCO sections and responses obtained are shown in the table below:

Table 3: Staff Involvement in Procurement Planning in their respective Sections

\begin{tabular}{lccc}
\hline Statement & Response & Frequency & Percent \\
\hline & Strongly Disagree & 9 & 6.8 \\
& Disagree & 43 & 32.3 \\
& Neutral & 18 & 13.5 \\
I am involved in procurement planning in & Agree & 41 & 30.8 \\
my section & Strongly Agree & 22 & 16.5 \\
& Total & $\mathbf{1 3 3}$ & $\mathbf{1 0 0 . 0}$ \\
\hline
\end{tabular}

\section{Source: Primary data}

Results in the table above show that, $9(6.8 \%)$ of the respondents strongly disagreed, $43(32.3 \%)$ disagreed, 18(13.5\%) were neutral, $41(30.8 \%)$ agreed and $22(16.5 \%)$ of them strongly agreed. Results obtained indicate that $63(47.3 \%)$ of the respondents generally agreed that indeed they are involved in procurement planning in their respective sections in MONUSCO sections at the MONUSCO Entebbe Support Base (ESB). During the interviews respondents revealed that "section heads work hand in hand with the end user departments to draft plans and specifications of goods and services needed for a particular requirement or peacekeeping operations under MONUSCO mandate so as to have them included in the annual procurement plan of the organization" smooth operations in the areas of humanitarian relief and peacekeeping missions. This has improved on the levels of MONUSCO procurement activities which have reduced on the levels of emergency procurements for specific operations.

\subsubsection{Early Annual Planning of Requirements and Determination of Material Acquisition}

Early and accurate planning is essential to avoid last minute, emergency or ill-planned procurement, which is contrary to open, efficient and effective and consequently transparent procurement. So the respondents were asked whether really early annual planning of requirements plays an important role in determination of acquisition of materials in MONUSCO sections and responses obtained are shown in table 4. The results show that, $3(2.3 \%)$ of the respondents disagreed, $4(3.0 \%)$ were neutral, $41(30.8 \%)$ agreed and $85(63.9 \%)$ of them strongly agreed. Results obtained indicate that $126(94.7 \%)$ of the respondents generally agreed that indeed early annual planning of requirements plays an important role in determination of acquisition of materials in MONUSCO sections at the MONUSCO Entebbe Support Base (ESB). During the interviews respondents revealed that "heads of departments conduct early materials and services planning for all operations of MONUSCO. This has helped them in early determination of the necessary materials for various operations under MONUSCO's mandate. 
The base has also in this way tried to reduce on the number of last minute, emergency or illplanned procurement.

Table 4: Early Annual Planning of Requirements and Determination of Material Acquisition

\begin{tabular}{lccc}
\hline Statement & Response & Frequency & Percent \\
\hline & Disagree & 3 & 2.3 \\
Early annual planning of requirements & Neutral & 4 & 3.0 \\
plays an important role in & Agree & 41 & 30.8 \\
determination of acquisition of materials & Strongly Agree & 85 & 63.9 \\
& Total & $\mathbf{1 3 3}$ & $\mathbf{1 0 0 . 0}$ \\
\hline
\end{tabular}

Source: Primary data

4.2.5 Procurement Planning and Achievement of Maximum Value for Expenditures on Goods/Services and Works to be Delivered

A procurement plan helps Procuring Entities to achieve maximum value for expenditures on services to be delivered and enables the entities to identify and address all relevant issues pertaining to a particular procurement of goods, works and services. So the respondents were asked whether really procurement planning contributes to achieve the maximum value for expenditures on goods/services and works to be delivered at MONUSCO sections and responses obtained are shown in the Table 5. Results in the table above show that, 4 (3\%) were neutral, 34 (25.6\%) agreed and 95 (71.4\%) of them strongly agreed. Results obtained indicate that 129 $(97 \%)$ of the respondents generally agreed that procurement planning contributes to achieve the maximum value for expenditures on goods/services and works to be delivered at MONUSCO sections at the MONUSCO Entebbe Support Base (ESB). During the interviews respondents revealed that "heads of departments conduct procurement planning and clearly clarify what is needed and when it is needed by the user department". This has contributed to achieving maximum value for all expenditures in procurement at MONUSCO ESB.

Table 5: Procurement Planning and Achievement of Maximum Value for Expenditures on Goods/Services and Works to be Delivered

\begin{tabular}{lccc}
\hline Statement & Response & Frequency & Percent \\
\hline & Neutral & 4 & 3.0 \\
$\begin{array}{l}\text { Procurement planning contributes to } \\
\text { achieve the maximum value for }\end{array}$ & Agree & 34 & 25.6 \\
$\begin{array}{l}\text { expenditures on goods/services and works } \\
\text { to be delivered }\end{array}$ & Strongly Agree & 95 & 71.4 \\
\hline
\end{tabular}

Source: Primary data

\subsubsection{Procurement Planning in Setting Motion for the entire Procurement Process}

Procurement planning is one of the primary functions of procurement with a potential to contribute to the success of departmental operations and is a function that sets in motion the entire acquisition/procurement process of acquiring services in organizations. So the respondents 
were asked whether really procurement planning sets in motion the entire procurement process at MONUSCO and responses obtained are shown in the Table 6 . The results show that, $1(0.8 \%)$ of the respondents strongly disagreed, $8(6 \%)$ were neutral, $56(42.1 \%)$ agreed and $68(51.1 \%)$ of them strongly agreed. Results obtained indicate that $124(93.2 \%)$ of the respondents generally agreed that really procurement planning sets in motion the entire procurement process in MONUSCO sections in MONUSCO ESB. During the interviews respondents revealed that "the procurement planning function has always set pace for the entire acquisition/procurement process of MONUSCO when acquiring goods and services for respective peace keeping missions". This has contributed to a reduction of emergency procurements and achieving maximum value for all procurements made at MONUSCO ESB.

Table 6: Procurement Planning in Setting Motion for the entire Procurement Process

\begin{tabular}{lccc}
\hline Statement & Response & Frequency & Percent \\
\hline & Strongly Disagree & 1 & 0.8 \\
& Neutral & 8 & 6.0 \\
Procurement planning sets in motion the & Agree & 56 & 42.1 \\
entire procurement process in my & Strongly Agree & 68 & 51.1 \\
organisation & Total & $\mathbf{1 3 3}$ & $\mathbf{1 0 0 . 0}$ \\
\hline
\end{tabular}

\section{Source: Primary data}

\subsubsection{Involvement of Top Management in Procurement Planning}

The respondents were asked whether MONUSCO top management is involved in the procurement planning and responses obtained are shown in the Table 7.

Table 7: Involvement of Top Management in Procurement Planning

\begin{tabular}{lccc}
\hline Statement & Response & Frequency & Percent \\
\hline & Strongly Disagree & 1 & .8 \\
& Disagree & 2 & 1.5 \\
& Neutral & 4 & 3.0 \\
Top management is involved in the & Agree & 50 & 37.6 \\
procurement planning & Strongly Agree & 76 & 57.1 \\
\hline
\end{tabular}

\section{Source: Primary data}

Results in the table above show that, $1(0.8 \%)$ of the respondents strongly disagreed, $2(1.5 \%)$ disagreed, 4 (3\%) were neutral, $50(37.6 \%)$ agreed and $76(57.1 \%)$ of them strongly agreed. Results obtained indicate that $136(94.7 \%)$ of the respondents generally agreed that indeed MONUSCO Top management is involved in the procurement planning in all MONUSCO sections in MONUSCO ESB. During the interviews respondents revealed that "the top management is involved in procurement planning of all requirements and services at the MONUSCO ESB". This has improved on the monitoring and evaluation of all activities involved in acquiring goods and services for the respective departments and sections in the mission. 


\subsubsection{Definition of Requirements after Need Identification}

Procurement process is the independent variable which can be measured based on procurement guidelines and policy, annual procurement planning, budget allocation, proper identification and definition of requirements and approvals. The respondents were asked whether really definition of requirements starts when a need is identified in MONUSCO and responses obtained are shown in Table 8 . The results show that, $2(1.5 \%)$ of the respondents disagreed, $2(1.5 \%)$ were neutral, $62(46.6 \%)$ agreed and $67(50.4 \%)$ of them strongly agreed. Results obtained indicate that 129 $(97 \%)$ of the respondents generally agreed that definition of requirements starts when a need is identified in MONUSCO ESB. During the interviews respondents revealed that "it is at this stage of the procurement planning function that materials, goods and services needed are defined in their respective categories and quantities needed by the user departments of MONUSCO". This has aided in the timely and accurate acquisition of goods and services for respective peacekeeping missions.

Table 8: Definition of Requirements after Need Identification

\begin{tabular}{lccc}
\hline Statement & Response & Frequency & Percent \\
\hline & Disagree & 2 & 1.5 \\
& Neutral & 2 & 1.5 \\
& Agree & 62 & 46.6 \\
Definition of requirements starts when a & Strongly Agree & 67 & 50.4 \\
need is identified & Total & $\mathbf{1 3 3}$ & $\mathbf{1 0 0 . 0}$ \\
\hline
\end{tabular}

\section{Source: Primary data}

\subsubsection{Timely Definition of Business Needs in Respective Sections}

Sourcing the right suppliers on time helps avoid cutting corners under rush procurement to meet deadlines or budget expenditures. The respondents were asked whether really their respective sections define their business needs on time and responses obtained are shown in the Table 9.

Table 9: Timely Definition of Business Needs in Respective Sections

\begin{tabular}{lccc}
\hline Statement & Response & Frequency & Percent \\
\hline & Strongly Disagree & 5 & 3.8 \\
& Disagree & 14 & 10.5 \\
& Neutral & 18 & 13.5 \\
& Agree & 61 & 45.9 \\
My section defines its business needs on & Strongly Agree & 35 & 26.3 \\
time & Total & $\mathbf{1 3 3}$ & $\mathbf{1 0 0 . 0}$ \\
\hline
\end{tabular}

\section{Source: Primary data}

Results in the table above show that, 5 (3.8\%) strongly disagreed, 14 (10.5\%) of the respondents disagreed, $18(13.5 \%)$ were neutral, $61(45.9 \%)$ agreed and $35(26.3 \%)$ of them strongly agreed. Results obtained indicate that $96(72.2 \%)$ of the respondents generally agreed that their respective sections define their business needs on time in MONUSCO ESB. During the interviews respondents revealed that "the heads of departments and sections are mandated to 
define, quantify and submit their procurement plans to the budget and acquisition department in order to be presented by the Director of MONUSCO who later submits them to the fifth committee in New York for timely budget allocation towards the mission's mandate every year month and prior the extension of MONUSCO mandate by the Security Council". This has aided in the timely sourcing and delivery of goods and services for respective peace keeping missions.

\subsubsection{Staff Involvement in the Identification and Definition of the Needs in Respective Sections}

By its very nature, procurement is a "service" function (Ishola, 2010) and is responsible on one hand for the identification of the end-user's needs and, by utilizing suppliers, meeting them. The respondents were asked whether really they are involved in the identification and definition of the needs of user sections and responses obtained are shown in the Table 10. Results in the table above show that, $9(6.8 \%)$ strongly disagreed, $42(31.6 \%)$ of the respondents disagreed, 21 (15.8\%) were neutral, $34(25.6 \%)$ agreed and 27 (20.3\%) of them strongly agreed. Results obtained indicate that $61(45.9 \%)$ of the respondents generally agreed that they are involved in the identification and definition of the needs of user sections at MONUSCO ESB. During the interviews respondents revealed that "the heads of sections involve all concerned staff in identification, classification and selection of needed materials, goods and services needed by the user departments MONUSCO". This has aided in full scale involvement of relevant stakeholders in the procurement planning activities of MONUSCO ESB.

Table 10: Staff Involvement in the Identification and Definition of the Needs in Respective Sections

\begin{tabular}{lccc}
\hline Statement & Response & Frequency & Percent \\
\hline & Strongly Disagree & 9 & 6.8 \\
& Disagree & 42 & 31.6 \\
& Neutral & 21 & 15.8 \\
& Agree & 34 & 25.6 \\
I am involved in the identification and & Strongly Agree & 27 & 20.3 \\
definition of the needs of my section & Total & $\mathbf{1 3 3}$ & $\mathbf{1 0 0 . 0}$ \\
\hline
\end{tabular}

Source: Primary data

\subsubsection{Knowledge of Product Quality as a key in Defining its Specifications}

Some of the high-level procurement activities include determining of specifications in terms of required quality and quantities. The respondents were therefore asked whether really they believe that knowing product quality is key in defining its specifications and responses obtained are shown in Table 11. The results show that, 1 (.8\%) disagreed, $3(2.3 \%)$ were neutral, $49(36.8 \%)$ agreed and $80(60.2 \%)$ of them strongly agreed. Results obtained indicate that $129(97 \%)$ of the respondents generally agreed that really they believe that knowing product quality is key in defining its specification in line with the needs of user sections in MONUSCO ESB. During the interviews respondents revealed that "knowledge of the products quality to be supplied to the user departments is key and very vital at the stage of product quotations and delivery to MONUSCO users' departments". This has aided the contract approval process which is based on the product specifications submitted by the end user departments in MONUSCO ESB. 
Table 11: Staff Involvement in the Identification and Definition of the Needs in Respective Sections

\begin{tabular}{lccc}
\hline Statement & Response & Frequency & Percent \\
\hline & Disagree & 1 & .8 \\
& Neutral & 3 & 2.3 \\
& Agree & 49 & 36.8 \\
I believe that knowing product quality is & Strongly Agree & 80 & 60.2 \\
key in defining its specifications & Total & $\mathbf{1 3 3}$ & $\mathbf{1 0 0 . 0}$ \\
\hline
\end{tabular}

\section{Source: Primary data}

\subsubsection{Staff Involvement in Specifying Products Specifications}

Even in situations where planning is difficult such as emergencies, proactive measures can be taken to ensure contingency planning through development of standard specifications all for products/services/works requested in emergency operations. So the respondents were therefore asked whether really they are involved in specifying products specifications and responses obtained are shown in the Table 12: Results in the table above show that, 12 (9\%) strongly disagreed, $43(32.3 \%)$ disagreed, $22(16.5 \%)$ were neutral, $36(27.1 \%)$ agreed and $20(15 \%)$ of them strongly agreed. Results obtained indicate that $56(42.1 \%)$ of the respondents generally agreed that they are involved in specifying products specifications in line with the needs of user sections in MONUSCO ESB. During the interviews respondents revealed that "most staff are involved in specifying the specification of different products and materials needed by the user departments"' in MONUSCO ESB.

Table 12: Staff Involvement in Specifying Products Specifications

\begin{tabular}{lccc}
\hline Statement & Response & Frequency & Percent \\
\hline & Strongly Disagree & 12 & 9.0 \\
& Disagree & 43 & 32.3 \\
& Neutral & 22 & 16.5 \\
& Agree & 36 & 27.1 \\
In my section, I am involved in specifying & Strongly Agree & 20 & 15.0 \\
products specifications & Total & $\mathbf{1 3 3}$ & $\mathbf{1 0 0 . 0}$ \\
\hline
\end{tabular}

\section{Source: Primary data}

\subsubsection{Development of Statement Of Requirements and Scope Of Work (SOW) in Respective Sections}

According the United Nations Procurement Manual (2008), The UN procurement process involves a wide-range of activities including: acquisition planning; drafting; reviewing or approving Specifications, SOWs and TORs among other activities. So the respondents were therefore asked whether really in their sections, they develop Statement of Requirements (SOR)/or Scope of Work (SOW) and responses obtained are shown in the table 13: 
Table 13: Development of Statement Of Requirements and Scope Of Work (SOW) in Respective Sections

\begin{tabular}{lccc}
\hline Statement & Response & Frequency & Percent \\
\hline & Strongly Disagree & 8 & 6.0 \\
& Disagree & 10 & 7.5 \\
& Neutral & 20 & 15.0 \\
In my section, we develop Statement Of & Agree & 46 & 34.6 \\
Requirements and Scope Of Work & Strongly Agree & 49 & 36.8 \\
\hline
\end{tabular}

Results in the table above show that, 8 (6\%) strongly disagreed, 10 (7.5\%) disagreed, 20 (15\%) were neutral, $46(34.6 \%)$ agreed and $49(36.8 \%)$ of them strongly agreed. Results obtained indicate that $95(71.4 \%)$ of the respondents generally agreed that in their sections, they develop Statement Of Requirements (SOR)/or Scope Of Work (SOW) for all user sections at MONUSCO ESB. During the interviews respondents revealed as per the United Nations Procurement Manual (2008), UN procurement process stipulates a wide range of activities including: acquisition planning; drafting; reviewing or approving Specifications, SOWs and TORs; identifying, registering and evaluating Vendors; preparing and developing Solicitations; evaluating Bids or Proposals; Source Selection; negotiating price or terms and conditions of Contracts; reviewing and approving awards of Contracts at MONUSCO ESB.

\subsubsection{The SOR or SOW is not important in my section}

The respondents were also asked whether really in their sections, the Statement Of Requirements (SOR)/or Scope Of Work (SOW) is not important in their respective sections and responses obtained are shown in the table below:

Table 14: Importance of SOR or SOW in Respective Sections

\begin{tabular}{lccc}
\hline Statement & Response & Frequency & Percent \\
\hline & Strongly Disagree & 80 & 60.2 \\
& Disagree & 28 & 21.1 \\
& Neutral & 11 & 8.3 \\
In my section, we develop Statement Of & Agree & 10 & 7.5 \\
Requirements and Scope Of Work & Strongly Agree & 4 & 3.0 \\
\hline
\end{tabular}

Results in the table above show that, $80(60.2 \%)$ strongly disagreed, $28(21.1 \%)$ disagreed, 11 $(8.3 \%)$ were neutral, $10(7.5 \%)$ agreed and $4(3 \%)$ of them strongly agreed. Results obtained indicate that $108(81.2 \%)$ of the respondents generally disagreed that in their sections, the Statement Of Requirements (SOR)/or Scope Of Work (SOW) is not important in their respective sections in MONUSCO ESB. During the interviews respondents revealed that "as per the United Nations Procurement Manual (2008), it is mandatory for all sections and user departments to develop Statement Of Requirements (SOR)/or Scope Of Work (SOW) for all procurements conducted". This implies that indeed the Statement Of Requirements (SOR)/or Scope Of Work (SOW) are very important for the respective sections at MONUSCO ESB. 


\subsubsection{Staff Training on Product Technical Specifications}

The respondents were further asked whether really they have ever received training on product technical specifications and responses obtained are shown in the Table 15.

Table 15: Staff Training on Product Technical Specifications

\begin{tabular}{lccc}
\hline Statement & Response & Frequency & Percent \\
\hline & Strongly Disagree & 23 & 17.3 \\
& Disagree & 17 & 12.8 \\
& Neutral & 9 & 6.8 \\
& Agree & 38 & 28.6 \\
I have ever received training on product & Strongly Agree & 46 & 34.6 \\
technical specifications & Total & $\mathbf{1 3 3}$ & $\mathbf{1 0 0 . 0}$ \\
\hline
\end{tabular}

Results in the table above show that, 23 (17.3\%) strongly disagreed, 17 (12.8\%) disagreed, 9 $(6.8 \%)$ were neutral, $38(28.6 \%)$ agreed and $46(34.6 \%)$ of them strongly agreed. Results obtained indicate that $84(63.2 \%)$ of the respondents generally agreed that they have ever received training on product technical specifications. During the interviews respondents revealed "The Regional Training Centre and Conference (RTCC) in Entebbe offered a range of trainings on other areas but not in product specifications as per the United Nations Procurement Manual (2008”). This implies that indeed most staff have not been trained in the procurement related activities in MONUSCO ESB.

\section{Hypothesis Tests}

$\mathbf{H}_{\mathbf{O}}$ : There is no significant relationship between procurement process and effective and efficient service delivery in MONUSCO.

$\mathbf{H}_{\mathrm{A}}$ : There is a significant relationship between procurement process and effective and efficient service delivery in MONUSCO.

Linear regression analysis was used to test the relationships between the variables. The model summary table below shows that $\mathrm{R}$ square was $2.3 \%$ of the observed variability in effective and efficient service delivery in MONUSCO explained by the independent variables: My section defines its business needs on time, Early annual planning of requirements plays an important role in determination of acquisition of materials., Funds are available before planning is done., There is a procurement planning in my section. $\mathrm{R}=0.152$ is the correlation coefficient between the observed value of the dependent variable and the predicted value based on the regression model.

Table 16: Model Summary

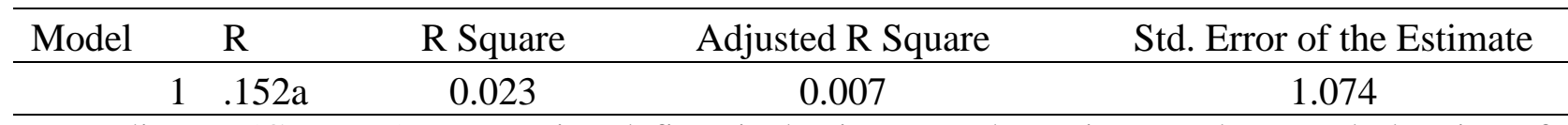

a. Predictors: (Constant), My section defines its business needs on time, Early annual planning of requirements plays an important role in determination of acquisition of materials, and funds are available before planning is done. There is a procurement planning in my section.

The analysis-of-variance (ANOVA) was also used by the study to test the equivalent null hypothesis. The $\mathrm{F}=0.757, \mathrm{p}<0.555$, the null hypothesis that there is no significant relationship between procurement process and effective and efficient service delivery in MONUSCO was not 
rejected, meaning that at least one of the population regression coefficient is zero. The results indicate that there is very weak positive relationship between procurement process and effective and efficient service delivery in MONUSCO.

Table 17: ANOVA ${ }^{\mathrm{a}}$

\begin{tabular}{|c|c|c|c|c|c|c|}
\hline \multicolumn{7}{|l|}{ Mode } \\
\hline \multirow[t]{3}{*}{1} & Regression & 3.49 & 4 & 0.872 & 0.757 & $.555 b$ \\
\hline & Residual & 147.608 & 128 & 1.153 & & \\
\hline & Total & 151.098 & 132 & & & \\
\hline
\end{tabular}

a. Dependent Variable: MONUSCO always offers the right $\mathrm{good} / \mathrm{service}$ at the right time.

b. Predictors: (Constant), My section defines its business needs on time; Early annual planning of requirements plays an important role in determination of acquisition of materials. Funds are available before planning is done. There is a procurement planning in my section.

The regression matrix tests what independent variable is more important to the dependent variable. The results in Table 18 show that section defines its business needs on time is the most significant independent variable to effective and efficient service delivery at MONUSCO because it has a t-statistic $=1.315, \mathrm{p}<0.191$. The means that procurement process in MONUSCO contributes to service delivery to a very small extent

Table 18: Coefficients ${ }^{\mathrm{a}}$

\begin{tabular}{|c|c|c|c|c|c|}
\hline \multirow[t]{2}{*}{ Model } & \multicolumn{2}{|c|}{$\begin{array}{l}\text { Unstandardized } \\
\text { Coefficients }\end{array}$} & \multirow{2}{*}{$\begin{array}{c}\begin{array}{c}\text { Standardized } \\
\text { Coefficients }\end{array} \\
\text { Beta }\end{array}$} & \multirow[t]{2}{*}{$\mathrm{t}$} & \multirow[t]{2}{*}{ Sig. } \\
\hline & $\mathrm{B}$ & Std. Error & & & \\
\hline (Constant) & 2.191 & .789 & & 2.776 & .006 \\
\hline There is a procurement planning in my section. & .041 & .105 & .038 & .388 & 699 \\
\hline $\begin{array}{l}\text { Funds are available before planning is done. } \\
1\end{array}$ & -.011 & .092 & -.012 & -.124 & .901 \\
\hline $\begin{array}{l}\text { Early annual planning of requirements plays an } \\
\text { important role in determination of } \\
\text { acquisition of materials. }\end{array}$ & -.100 & .142 & -.062 & -.706 & .481 \\
\hline My section defines its business needs on time & .124 & .094 & .123 & 1.315 & .191 \\
\hline
\end{tabular}

a. Dependent Variable: MONUSCO always offers the right good/service at the right time.

$\mathbf{H}_{\mathbf{0}}$ : Stakeholders do not play significant role during Procurement Process in MONUSCO to ensure effective and efficient service delivery.

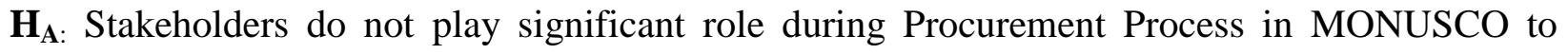
ensure effective and efficient service delivery 
The hypothesis was tested with a linear regression analysis; the model summary under table below shows the $\mathrm{R}$ square was $5.8 \%$ of the observed variability in role played during Procurement Process in MONUSCO to ensure effective and efficient service delivery explained by the independent variables that is; Vendor's management helps to identify non-performing suppliers, In my section, I am involved in specifying products specifications, Top management is involved in the procurement planning, In my section, we develop Statement Of Requirements (SOR)/or Scope Of Work (SOW)., I am involved in the identification and definition of the needs of my section. $\mathrm{R}=0.241$ is the correlation coefficient between the observed value of the dependent variable and the predicted value based on the regression model.

Table 19: Model Summary

\begin{tabular}{lllll}
\hline Model & $\mathrm{R}$ & R Square & Adjusted R Square & Std. Error of the Estimate \\
\hline 1 & $.241^{\mathrm{a}}$ & .058 & .021 & 1.037
\end{tabular}

a. Predictors: (Constant), Vendor's management helps to identify non-performing suppliers., In my section, I am involved in specifying products specifications, Top management is involved in the procurement planning, In my section, we develop Statement Of Requirements (SOR)/or Scope Of Work (SOW)., I am involved in the identification and definition of the needs of my section

The analysis-of-variance (ANOVA) table was also used by the study to test the equivalent null hypothesis. The $\mathrm{F}=1.554, \mathrm{p}<0.178$, the null hypothesis that Stakeholders do not play significant role during Procurement Process in MONUSCO to ensure effective and efficient service delivery was not rejected, meaning that at least one of the population regression coefficient is zero. The results indicate that that an increase in the independent variables will result in to a slight corresponding increase in service delivery.

Table 20: ANOVA ${ }^{\mathrm{a}}$

\begin{tabular}{rlrrrrr}
\hline Model & Sum of Squares & df & Mean Square & \multicolumn{1}{l}{ F } & \multicolumn{1}{l}{ Sig. } \\
\hline 1 & Regression & 8.358 & 5 & 1.672 & 1.554 & $.178 \mathrm{~b}$ \\
& Residual & 135.521 & 126 & 1.076 & & \\
& Total & 143.879 & 131 & & &
\end{tabular}

a. Dependent Variable: MONUSCO always offers the right good/service at the right time.

b. Predictors: (Constant), Vendor's management helps to identify non-performing suppliers., In my section, I am involved in specifying products specifications, Top management is involved in the procurement planning, In my section, we develop Statement Of Requirements (SOR)/or Scope Of Work (SOW)., I am involved in the identification and definition of the needs of my section 
The regression matrix below tests what independent variable is more important to the dependent variable. The results show that I am involved in the identification and definition of the needs of my section is the most significant independent variable to effective and efficient service delivery because it has a t-statistic $=1.004, \mathrm{p}<0.317$. This indicates that there is a weak correlation with the dependent variable.

Table 21: Coefficients ${ }^{\mathrm{a}}$

\begin{tabular}{|c|c|c|c|c|c|c|}
\hline \multicolumn{2}{|c|}{ Model } & \multicolumn{2}{|c|}{$\begin{array}{l}\text { Unstandardized } \\
\text { Coefficients }\end{array}$} & \multirow{2}{*}{$\begin{array}{c}\text { Standardized } \\
\text { Coefficients } \\
\text { Beta }\end{array}$} & \multirow[t]{2}{*}{$\mathrm{t}$} & \multirow[t]{2}{*}{ Sig. } \\
\hline & & B & Std. Error & & & \\
\hline & (Constant) & 2.436 & .751 & & 3.242 & .002 \\
\hline & $\begin{array}{l}\text { Top management is involved in the } \\
\text { procurement planning }\end{array}$ & .006 & .160 & 0.004 & .039 & .969 \\
\hline & $\begin{array}{l}\text { I am involved in the identification and } \\
\text { definition of the needs of my section }\end{array}$ & .120 & .119 & 0.145 & 1.004 & .317 \\
\hline 1 & $\begin{array}{l}\text { In my section, I am involved in } \\
\text { specifying products specifications }\end{array}$ & .062 & .140 & 0.073 & 0.440 & .661 \\
\hline & $\begin{array}{l}\text { In my section, we develop Statement Of } \\
\text { Requirements (SOR)/or } \quad \text { Scope Of } \\
\text { Work (SOW). }\end{array}$ & -.244 & .109 & -.266 & -2.243 & .027 \\
\hline & $\begin{array}{l}\text { Vendor's management helps to identify } \\
\text { non-performing suppliers. }\end{array}$ & .053 & .136 & .037 & .389 & .698 \\
\hline
\end{tabular}

a. Dependent Variable: MONUSCO always offers the right good/service at the right time.

\subsection{SUMMARY OF FINDINGS, CONCLUSIONS AND RECOMMENDATIONS}

\subsection{Summary of Findings}

The study revealed that, $110(82.7 \%)$ of the respondents generally agreed that indeed there is procurement planning in most MONUSCO sections in Entebbe Support Base. During the interviews, respondents revealed that "section heads are mandated to conduct thorough planning of the procurement activities and requirements for smooth service delivery" in MONUSCO ESB. The study also revealed that that $97(72.9 \%)$ of the respondents generally agreed that indeed Funds are available before planning is done in MONUSCO sections. During the interviews, respondents revealed that "section heads are still required and mandated to draw section budgets related to procurement activities so as to have them included in the annual organizations budgets" for availability of funds needed for smooth service delivery" in MONUSCO Entebbe Support Base. This has improved on the levels of MONUSCO operations in the areas of humanitarian relief, peacekeeping, development assistance to affected communities. 
The current study further established that $63(47.3 \%)$ of the respondents generally agreed that indeed they are involved in procurement planning in their respective sections in MONUSCO sections in MONUSCO ESB. During the interviews respondents revealed that "section heads work hand in hand with the end user departments to draft plans and specifications of goods and services needed for a particular requirement or operations under MONUSCO mandate so as to have them included in the annual procurement plan of the organisation". This has improved on the levels of MONUSCO procurement activities which have reduced on the levels of emergency procurements for specific operations.

The study further revealed that that 129 (97\%) of the respondents generally agreed that procurement planning contributes to achieve the maximum value for expenditures on goods/services and works to be delivered at MONUSCO sections at the MONUSCO Entebbe Support Base. During the interviews respondents revealed that "heads of departments conduct procurement planning and clearly clarify what is needed and when it is needed by the user department". This has contributed to achieving maximum value for all expenditures in procurement at MONUSCO Entebbe Support Base.

The study findings also revealed that that $61(45.9 \%)$ of the respondents generally agreed that they are involved in the identification and definition of the needs of user sections in MONUSCO ESB. During the interviews, respondents revealed that "the heads of sections involve all concerned staff in identification, classification and selection of needed materials, goods and services needed by the user departments in MONUSCO". This has aided in full scale involvement of relevant stakeholders in the procurement planning activities of MONUSCO ESB.

The study findings also showed that $108(81.2 \%)$ of the respondents generally disagreed that in their sections, the Statement of Requirements (SOR)/or Scope of Work (SOW) is not important in their respective sections in MONUSCO. During the interviews respondents revealed that "as per the United Nations Procurement Manual (2008), it is mandatory for all sections and user departments to develop Statement of Requirements (SOR)/or Scope of Work (SOW) for all procurements conducted". This implies that indeed the Statement of Requirements (SOR)/or Scope of Work (SOW) are very important for the respective sections in MONUSCO ESB.

\subsection{Recommendations}

The study considers that there should be a clear determination of specifications in terms of required quality and quantities by the end-user departments in MONUSCO ESB. Planning and determination of needs should be early identified to allow enough time to initiate the procurement process. The procurement department should always engage all concerned stakeholders in determining the materials and service specification for quality assurance during service delivery. This will enable the sections to always get the quantity of items as requested by end-users, in their right quantity, right quality and at the right time.

\section{REFERENCES}

Adams, B. \& Colebourne, P. (1989). The role of financial management in service organizations. In: P. Jones (Ed.) Management in Service Industries (London, Pitman Publishing), pp. 223-233. 
Agaba, E., \& Shipman, N. (2007). Public procurement reform in developing countries: The Ugandan experience. Advancing Public Procurement: Practices, Innovation and Knowledge-Sharing, 373-391.

Armstrong, M. (2001). A hand book of human resource management, ( $8^{\text {th }}$ ed.). Kogan Page London, UK.

Bailey, P., Farmer, D., Jessop, D., \& Jones, D. (1998). Purchasing principles and management, ( $8^{\text {th }}$ ed.). Edinburgh, Prentice Hall.

Baily, P., Farmer, D., Jessop D., \& Jones, D. (2005). Purchasing principles and management. UK.: Pearson education Limited.

Balunywa, M. (2004). Decentralization and service delivery in Uganda: The case of contracting out road construction services in Jinja District. Kampala. Makerere University Library.

Basheka, B. (2004). Procurement planning and local governance in Uganda: A factor analysis approach. Organisation: Uganda Management institute.

Basheka, B. C. (2008). Procurement planning and local governance in Uganda: A factor analysis approach. Paper Presented at the 2008 International Research Society for Public Management Conference, from 26-28 March 2008, in Brisbarne, Australia.

Basheka, B. C., (2008). Procurement planning and accountability of local Government procurement systems in developing countries: Evidence from Uganda, Journal of Public Procurement, 8(3), 379 - 406.

Bashuna, A. (2013). Factors affecting effective management of the procurement function at Nakuru North Sub-County, International Journal of Business and Management, 1(7).

Brammer, S., \& Walker, H. (2007). Sustainable procurement in the United Kingdom public sector. University of Bath School of Management Working Paper Series.

Chartered institute of Purchasing and Supply Austria, 2005

Defee, C., Williams, B., Randall, W. S., \& Thomas, R. (2010). An inventory of theory in logistics and SCM research. The International Journal of Logistics Management, 21(93), 404-489.

Demchenko, Y. (2009). Service delivery framework and services lifecycle management in ondemand services/resources provisioning, WP 2/W P3 Technical document, Version 0.2

Development Assistance Committee (2005). Harmonizing donor practices for effective aid delivery. Vol. 3. Strengthening procurement capacities in developing countries. Paris, France: OECD Development Assistance Committee, 2005; 18. 
Godfrey, A. B. (2012). Purpose driven research? The critical key to successful partnerships. proceedings of 2012 AUTEX World Technical Conference. Publisher: Association of Universities of Textiles: Ghent, BE.

Helmsing, A. H. J. (1995). Local government central finance: An introduction. New York USA.

Helmsing, J. (1995). Decentralisation and emerging patterns of local governance: A comparative analysis of Uganda, Zimbabwe and Zambia. Institute of social studies (ISS).

Hernon, P., \& Whitman, J. R. (2001). Delivering satisfaction and service quality: A customerbased approach for libraries. Chicago: American Library Association.

Hui, W. S., Othman, O., Rahman, R. A., \& Haron, N. H. (2011). Procurement issues in Malaysia. International Journal of Public Sector management, 24(6), 567-593.

Ishola T.O, (2010). Procurement and supply management. National Open University of Nigeria.

Johan, N. (2006). Planning for service delivery improvement. S D R Vol. 15(2), 106-109.

Kansiime, Apollo (2013). The impact of public procurement reforms on service delivery in Uganda. A case study of Kabale Municipality, Kabale district.

Kattel, R., \& Lember, V. (2010). Public procurement as an industrial policy tool: An option for developing countries? Journal of Public Procurement, 10(3), 368-404

Kelley, D., Bosma, N. S., Amorós, J. E. B. (2011). Global Entrepreneurship Monitor 2010 Executive Report, Utrecht University Repository (Report)

Khattab, A. S. (2005). The impact of information technology on customer services in Jordanian banking sector: University of Salford.

Knack, S., \& Rahman, A. (2009). Donor fragmentation and bureaucratic quality in aid recipients. Journal of Development Economics, 83(1), 176-97.

Lisa, I. (2010). Compliance culture: A conceptual framework. Journal of management and organization, 19 (7), 702-714.

Lysons, K., \& Farrington, B. (2006). Purchasing and supply chain management (7 ${ }^{\text {th }}$ ed.). Prentice Hall, FT.

Nichols, P. (2002). Regulating transnational bribery in times of globalization and fragmentation. The Yale Journal of Internal law, 24(1), 257-304. 
Nyeko, P. K., \& Kakwezi, P. (2004). Procurement Processes and Performance: Efficiency and Effectiveness of the Procurement Function. International Journal of Business and Commerce, 3(1), 54-70.

Obanda, W. (2011). Small and medium enterprises (SMEs) and public procurement contract in developing countries. Kampala: Longhorn publishers.

Obanda, W. P. (2010). Fighting corruption in tactical procurement. PHD dissertation.

Oboth, M. J. (2001). Decentralization and service delivery: Constraints and controversies. Kampala: Makerere University Library.

OECD, (2005). Harmonizing donor practices for effective aid delivery: Strengthening procurement capacities in developing countries, Development Assistance Committee, Vol. 3. Paris, France.

Parasuraman, A., Berry, L. L., \& Zeithaml, A. V. (1996). The behavioural consequences of service quality. Financial Times.

Parasuraman, A., Zeithaml, A., \& Berry, L. (1993). Research note: More on improving service quality measurement, Journal of Retailing,(1), 140-7.

Scott, W. Richard (2004). Institutional theory. Pp. 408-14 in Encyclopaedia of Social Theory, George Ritzer, ed. Thousand Oaks, CA: Sage

Simchi-Levi, D., Simchi-Levi, E., \& Kaminsky, P. (1999). Designing and managing the supply chain: Concepts, strategies, and cases. New York: McGraw-Hill

Sutinen, J. G \& Kuperan, K. (1999). A Socio-economic theory of regulatory compliance. International Journal of Social Economics, 26 (1/2/3), 174-193

Thai, K. V. (2009). Introduction to Public Procurement, (5 ${ }^{\text {th }}$ ed.). Florida Atlantic University.

Tumugabiirwe, K. (2011). Procurement planning and service delivery in Local Government: A case study of Ibanda Town Council.

UN Procurement Practitioner's Handbook, 2006.

United Nations Procurement Manual, Revision 7 (2013), Department of Management, Office of Central Support Services, Procurement Division.

World Bank Institute (WBI) and Public-Private Infrastructure Advisory Facility (PPIAF), (2013). Value-for-money analysis practices and challenges: How governments choose when to Use PPP to deliver public infrastructure and services. Report from World Bank Global Round-Table 28 May, 2013, Washington DC. 